\title{
Effects of maternal undernutrition and exercise on glucose kinetics in fetal sheep
}

\author{
BY B. J. LEURY*, K. D. CHANDLER, A. R. BIRD† AND A. W. BELL \$ \\ School of Agriculture, La Trobe University, Bundoora, Victoria 3083, Australia
}

(Received 12 December 1989 - Accepted 18 April 1990)

\begin{abstract}
Fetal glucose kinetics were measured using a combination of isotope-dilution and Fick-principle methodology in single-pregnant ewes which were either well-fed throughout, or fed at 0.3-0.4 predicted energy requirement for 7-21 d during late pregnancy. All ewes were studied while standing at rest and then while walking on a treadmill at $0.7 \mathrm{~m} / \mathrm{s}$ on a $10^{\circ}$ slope for 60 min. Underfed ewes suffered major decreases in fetal total disposal rate, fetal-placental transfer and umbilical net uptake of glucose, each of which were significantly related to declines in maternal and fetal blood glucose concentrations respectively. In well-fed ewes, fetal endogenous glucose production was negligible, as indicated by the similarity between fetal utilization rate (total glucose disposal rate minus placental uptake of fetal glucose) and umbilical net uptake of glucose, and by nearly identical fetal and maternal arterial blood specific radioactivities of maternally infused $D-\left[2-{ }^{3} \mathrm{H}\right]$ glucose. By contrast, in underfed ewes, fetal utilization rate greatly exceeded umbilical net uptake of glucose, and the fetal:maternal $\left.\right|^{3} \mathrm{H} \mid$ glucose specific activity ratio declined significantly, suggesting induction of a substantial rate of fetal endogenous glucogenesis. Exercise caused increases in fetal total glucose disposal rate and glycaemia in fed and underfed ewes. In underfed ewes only, this was accompanied by increased placental uptake of fetal glucose and umbilical net glucose uptake, unchanged fetal glucose utilization and decreased fetal endogenous glucose production. It is concluded that fetal gluconeogenesis makes a major contribution to fetal glucose requirements in undernourished ewes. Increased maternal supply of fetal glucose during exercise substitutes for rather than adds to fetal endogenous glucogenesis.
\end{abstract}

Fetus: Glucose utilization: Glucose production: Sheep

Umbilical uptake of glucose by fetal sheep is substantially reduced by maternal starvation for several days (Tsoulos et al. 1971; Boyd et al. 1973) or longer-term undernutrition (Chandler et al. 1985; Leury et al. 1990). However, Hay et al. (1984) used isotope-dilution techniques to demonstrate that in starved ewes, the rate of fetal glucose utilization was less affected than umbilical uptake, implying a significant rate of endogenous glucose production in the hypoglycaemic fetus. In the present study we have used similar techniques to investigate the possibility of fetal endogenous glucose production during longer periods of maternal undernutrition, with implications for the likely importance of gluconeogenesis $v$. glycogenolysis as the source of fetal glucogenesis. Ewes were studied at rest and during exercise to determine the origins of exercise-induced fetal hyperglycaemia (Chandler \& Bell, 1981; Bell et al. 1983). We also sought a kinetic explanation for our previous observation that changes in fetal glucose metabolism during maternal exercise were considerably greater in underfed than in well-fed ewes (Leury et al. 1990). Some of these results have been reported in a short communication (Leury et al. 1989).

Present addresses: * Rutherglen Research Institute, Department of Agriculture and Rural Affairs, Rutherglen, Victoria 3685, Australia; $\uparrow$ Toorak Research Station, Department of Primary Industries, Julia Creek, Queensland 4823, Australia; $\ddagger$ Department of Animal Science, Cornell University, Ithaca, New York 14853-4801, USA.

$\S$ For reprints. 


\section{MATERIALS AND METHODS}

\section{Animals and management}

Sixteen single-pregnant, multiparous Merino ewes weighing $35-54 \mathrm{~kg}$ and with known mating dates were used. These animals were a large sub-group of those whose management, housing, surgical implantation of maternal and fetal catheters and post-operative care are detailed in the preceding paper on maternal and uterine glucose metabolism in the pregnant ewe (Leury et al. 1990). Briefly, ewes were brought indoors at 80-100 d post-coitus (pc) and at $115-120 \mathrm{~d}$ pc had catheters surgically implanted in the maternal abdominal aorta, uterine vein draining the pregnant uterine horn, common umbilical vein, fetal abdominal aorta and fetal posterior vena cava.

\section{Feeding treatments}

Ewes were given 800-1200 g lucerne (Medicago sativa) chaff (metabolizable energy (ME) content approximately $9 \mathrm{MJ} / \mathrm{kg}$ ) $/ \mathrm{d}$, according to body-weight and stage of pregnancy, until surgery. After they had reattained presurgery feed intakes (usually $2-3 \mathrm{~d}$ post-surgery) they were randomly assigned to one of two nutritional treatments: eight ewes were given $1000-1200 \mathrm{~g}$ lucerne chaff/d (fed group) and the remaining eight were given $350 \mathrm{~g}$ lucerne chaff/d (underfed group), until they were slaughtered at 140-144 d pc. In both groups the daily ration was given in twelve equal portions at two-hourly intervals, with ad lib. access to water and a mineralized salt block (Cheetham Salt, Geelong, Australia). The entire ration was consumed by all ewes throughout the experimental period.

\section{Experimental procedure}

Experiments were performed on fed ewes at least $7 \mathrm{~d}$ after surgery, when they were at 123-137 d pc, and on underfed ewes at 10-22 d after surgery, when they had been underfed for $7-21 \mathrm{~d}$, and were at $124-137 \mathrm{~d}$ pc. Where possible, two studies per animal were attempted, with an interval of at least 1 week between studies. Ewes were killed with an overdose of sodium pentobarbitone at $140-144 \mathrm{~d}$ pc to measure weights of the pregnant uterus, fetus and placenta.

On the day of study, experimental infusions were begun at least $45 \mathrm{~min}$ after the ewe had been placed on the stationary treadmill. D- $\left[2 \cdot{ }^{3} \mathrm{H}\right]$ glucose (nominal specific activity $15 \mathrm{Ci} / \mathrm{mmol}$; Amersham International plc, Amersham, Bucks), dissolved in sterile isotonic saline ( $9 \mathrm{~g}$ sodium chloride/1), was given by primed continuous infusion into a maternal jugular vein (priming dose $80 \mu \mathrm{Ci}$, followed by continuous infusion at $0 \cdot 8 \mu \mathrm{Ci} / \mathrm{min}$ ). At the same time, a priming dose of $40 \mu \mathrm{Ci}$ D- $\left[\mathrm{U}-{ }^{14} \mathrm{C}\right]$ glucose (nominal specific activity $300 \mathrm{mCi} / \mathrm{mmol}$; Amersham International plc) in sterile isotonic saline was injected into the fetal vena cava and followed by continuous infusion at $0.4 \mu \mathrm{Ci} / \mathrm{min}$. The latter infusate also contained antipyrine, which was infused at $20-30 \mathrm{mg} / \mathrm{min}$ for measurement of umbilical and uterine blood flows. Blood samples were simultaneously drawn from the maternal aorta and uterine vein (each $5 \mathrm{ml}$ ), fetal aorta and common umbilical vein (each $1.2 \mathrm{ml}$ ) at about $90,110,130$ and $150 \mathrm{~min}$ after infusions commenced, while the ewe stood at rest. Additional maternal and fetal arterial samples were taken at about 100, 120 and $140 \mathrm{~min}$.

The ewe then commenced walking $\left(0.7 \mathrm{~m} / \mathrm{s}, 10^{\circ}\right.$ slope $)$ and the previously described sampling routine was repeated after about 40,50 and $60 \mathrm{~min}$ of exercise. Additional maternal and fetal arterial samples were taken after 5, 10, 15,20 and $30 \mathrm{~min}$ of exercise.

Blood samples for analysis of glucose concentration and specific radioactivity (SRA) and of antipyrine were stored on ice in capped, heparinized syringes before being deproteinized with zinc sulphate-barium hydroxide; extracts were stored at $-20^{\circ}$. 


\section{Measurements}

Uterine and umbilical blood flows were measured by the transplacental steady-state diffusion technique (Meschia et al. 1967). Blood concentrations of antipyrine were measured by the method of Brodie et al. (1949), as modified by Chandler (1983). Blood glucose was analysed by the glucose oxidase $(E C 1.1 .1 .34)$ method of Bergmeyer \& Bernt (1974). Glucose SRA was determined after anion-exchange chromatography, freeze-drying to remove ${ }^{3} \mathrm{H}_{2} \mathrm{O}$ and reconstitution in $0.5 \mathrm{ml}$ water; the procedures were essentially those of Hay et al. (1981) as slightly modified by Leury (1987). In fetal samples, labelled glucose was separated from labelled fructose by pretreatment of the protein-free filtrate with glucose oxidase, and glucose activity was measured by difference between activities of anion-exchange eluates from untreated and treated samples (Hay et al. 1981). Recovery from fetal blood spiked with a known amount of $\left[{ }^{14} \mathrm{C}\right]$ glucose was not less than $98 \%$. Retention of $\left[{ }^{14} \mathrm{C}\right]$ gluconate or unconverted $\left[{ }^{14} \mathrm{C}\right]$ glucose, or both, after treatment with glucose oxidase was $90-98 \%$. This was corrected for by inclusion of a standard $\left[{ }^{14} \mathrm{C}\right] \mathrm{glucose}$ solution in each assay. Samples derived from blood extracts and infusates for a given experiment were counted at the same time in a Packard Tricarb $460 \mathrm{C}$ liquid-scintillation system (Packard Instrument Co., IL, USA).

\section{Calculations}

The model developed by Hay et al. (1984) was used to calculate and simultaneously compare rates of fetal glucose disposal and utilization, and umbilical net glucose uptake. Fetal glucose disposal rate $(\mu \mathrm{mol} / \mathrm{min})$ was calculated by dividing the steady-state infusion rate of $\left[{ }^{14} \mathrm{C}\right]$ glucose into the fetus (disintegrations/min $(\mathrm{dpm})$ per $\mathrm{min}$ ) by fetal blood glucose SRA $(\mathrm{dpm} / \mu \mathrm{mol})$ after the latter was no longer time-dependent. This occurred within $90 \mathrm{~min}$ in almost every case. Fetal glucose utilization rate $(\mu \mathrm{mol} / \mathrm{min})$ was calculated similarly, except that in the numerator, $\left[{ }^{14} \mathrm{C}\right]$ glucose taken up by the placenta (umbilical blood flow $\times$ umbilical arterio-venous difference in $\left[{ }^{14} \mathrm{C}\right]$ glucose activity) was subtracted from the fetal infusion rate. Umbilical net glucose uptake $(\mu \mathrm{mol} / \mathrm{min})$ was calculated as the product of umbilical blood flow $(\mathrm{ml} / \mathrm{min})$ and umbilical venous-arterial glucose concentration difference $(\mu \mathrm{mol} / \mathrm{ml})$. Fetal endogenous glucose production rate $(\mu \mathrm{mol} / \mathrm{min})$ was estimated as the difference between fetal glucose utilization rate and umbilical net glucose uptake (Hay et al. 1984).

Although fetal hyperglycaemia occurred almost invariably during maternal exercise, fetal blood glucose SRA during the final $30 \mathrm{~min}$ of the $60 \mathrm{~min}$ exercise period varied less than $10 \%$ between successive samples and showed no statistically significant timedependence in almost every case. Therefore, fetal glucose SRA were considered to have reached a new steady-state and calculations of fetal glucose kinetics during maternal exercise were identical to those for the resting state.

\section{Statistics}

Where more than one study was done per animal, the values were averaged before statistical analysis of treatment effects. The significance of the effects of exercise were assessed by the paired $t$ test. Effect of undernutrition on resting absolute values and on exercise-induced changes from resting values were assessed by the unpaired $t$ test. Relations between variables were determined by least squares linear regression analysis. 
Table 1. Effects of undernutrition and exercise on maternal and fetal arterial blood glucose concentrations in ewest

(Values are means with their standard errors; no. of studies and no. of sheep respectively in parentheses)

\begin{tabular}{|c|c|c|c|c|c|c|c|c|c|c|}
\hline \multirow[b]{3}{*}{ Glucose } & \multicolumn{4}{|c|}{ Fed } & \multicolumn{4}{|c|}{ Underfed } & \multirow{2}{*}{\multicolumn{2}{|c|}{$\begin{array}{l}\text { Effect of } \\
\text { nutrition }\end{array}$}} \\
\hline & \multicolumn{2}{|c|}{$\mathrm{R}$} & \multicolumn{2}{|c|}{$\Delta \mathrm{E}$} & \multicolumn{2}{|c|}{$\mathrm{R}$} & \multicolumn{2}{|l|}{$\Delta \mathrm{E}$} & & \\
\hline & Mean & SE & Mean & $\mathrm{SE}$ & Mean & $\mathrm{SE}$ & Mean & $\mathrm{SE}$ & $\mathrm{R}$ & $\Delta \mathrm{E}$ \\
\hline $\begin{array}{l}\text { Maternal concentration } \\
(\mathrm{mmol} / \mathrm{l})\end{array}$ & $2 \cdot 81$ & $0 \cdot 10$ & $\begin{array}{l}+0 \cdot 39 \\
8)\end{array}$ & $0 \cdot 22$ & 1.55 & $0 \cdot 13$ & $\begin{array}{l}+1 \cdot 03^{* *} \\
(9,8)\end{array}$ & $0 \cdot 21$ & $* * *$ & NS \\
\hline $\begin{array}{l}\text { Fetal concentration } \\
(\mathrm{mmol} / \mathrm{l})\end{array}$ & 0.71 & 0.05 & $\begin{array}{l}+0 \cdot 17^{*} \\
8)\end{array}$ & $0 \cdot 06$ & $0 \cdot 30$ & $0 \cdot 04$ & $\begin{array}{l}+0 \cdot 42^{* * * *} \\
(9,8)\end{array}$ & 0.06 & $* * *$ & $* *$ \\
\hline
\end{tabular}

$\mathrm{R}$, rest; $\Delta \mathrm{E}$, change with exercise; NS, not significant

* $P<0.05$, ** $P<0.01, * * * P<0.001$.

$\dagger$ For details of procedures, see p. 464.

Table 2. Effects of undernutrition and exercise on ratios of fetal:maternal blood specific activity of maternally infused $\left[{ }^{3} \mathrm{H}\right]$ glucose and of maternal:fetal blood specific activity of fetally infused $\left[{ }^{14} \mathrm{C}\right] \mathrm{glucose}$ in ewes $\dagger$

(Values are means with their standard errors; no. of studies and no. of sheep respectively in parentheses)

\begin{tabular}{|c|c|c|c|c|c|c|c|c|c|c|}
\hline & \multicolumn{4}{|c|}{ Fed } & \multicolumn{4}{|c|}{ Underfed } & \multirow{2}{*}{\multicolumn{2}{|c|}{$\begin{array}{l}\text { Effect of } \\
\text { nutrition }\end{array}$}} \\
\hline & \multicolumn{2}{|c|}{$\mathrm{R}$} & \multicolumn{2}{|c|}{$\Delta \mathrm{E}$} & \multicolumn{2}{|c|}{$\mathrm{R}$} & \multicolumn{2}{|c|}{$\Delta \mathrm{E}$} & & \\
\hline & Mean & $\mathrm{SE}$ & Mean & SE & Mean & SE: & Mean & $\mathrm{SE}$ & $\mathbf{R}$ & $\Delta \mathrm{E}$ \\
\hline $\begin{array}{l}\text { Fetal: maternal } \\
{\left[{ }^{3} \mathrm{H}\right] \text { glucose }}\end{array}$ & 0.93 & 0.04 & $(10,8)^{-0.09}$ & 0.05 & 0.72 & 0.03 & ${ }^{-0.15}$ & 0.07 & $* *$ & NS \\
\hline $\begin{array}{c}\text { Maternal : fetal } \\
{\left[{ }^{14} \mathrm{C}\right] \text { glucose }}\end{array}$ & $0 \cdot 18$ & 0.02 & $(8,7)^{-0.04^{*}}$ & 0.01 & $0 \cdot 18$ & 0.02 & $\begin{array}{l}+0.04 \\
6)\end{array}$ & 0.04 & NS & NS \\
\hline
\end{tabular}

$\mathrm{R}$, rest; $\Delta \mathrm{E}$, change with exercise; NS, not significant.

$* P<0 \cdot 05, * * P<0 \cdot 01$.

$\dagger$ For details of procedures, see p. 464.

\section{RESULTS}

\section{Fetal and placental weights}

Mean (with SE) fetal and placental weights at 140-144 d pc in fed ewes (3.77 (SE 0.14) kg and 367 (SE 23) g respectively) were not significantly different from those in underfed ewes (3.54 (SE 0.24) $\mathrm{kg}$ and 358 (SE 46) g respectively).

Maternal and fetal glycaemia and tracer glucose specific activity ratios

Maternal and fetal arterial blood glucose concentrations were reduced by 45 and $58 \%$ respectively (both $P<0.001$ ) in underfed ewes (Table 1 ). The mean ratio of fetal: maternal SRA of maternally infused $\left[{ }^{3} \mathrm{H}\right]$ glucose in well-fed ewes $(0.93$ (SE 0.04)) was not significantly different from unity, but was decreased significantly $(P<0.01)$ in the underfed group $(0.72$ (SE 0.03); Table 2). Maternal: fetal ratios of fetally infused $\left[{ }^{14} \mathrm{C}\right]$ glucose were much lower and not affected by undernutrition (Table 2).

Exercise caused significant increases in maternal blood glucose concentration in underfed ewes $(P<0.01)$, and in fetal blood glucose concentration in fed $(P<0.05)$ and underfed ewes $(P<0 \cdot 001)$ (Table 1). The exercise-induced increase in maternal glycaemia tended to 
Table 3. Effects of undernutrition and exercise on fetal total disposal rate, utilization rate, umbilical net uptake, endogenous production rate and fetal-placental transfer of glucose in ewest

(Values are means with their standard errors; no. of studies and no. of sheep respectively in parentheses)

\begin{tabular}{|c|c|c|c|c|c|c|c|c|c|c|}
\hline \multirow{3}{*}{$\begin{array}{l}\text { Glucose flux rate } \\
(\mu \mathrm{mol} / \mathrm{min})\end{array}$} & \multicolumn{4}{|c|}{ Fed } & \multicolumn{4}{|c|}{ Underfed } & \multirow{2}{*}{\multicolumn{2}{|c|}{$\begin{array}{l}\text { Effect of } \\
\text { nutrition }\end{array}$}} \\
\hline & \multicolumn{2}{|c|}{$\mathrm{R}$} & \multicolumn{2}{|c|}{$\Delta \mathrm{E}$} & \multicolumn{2}{|c|}{$\mathrm{R}$} & \multicolumn{2}{|c|}{$\Delta \mathrm{E}$} & & \\
\hline & Mean & SE & Mean & $\mathrm{SE}$ & Mean & $\mathrm{SE}$ & Mean & $\mathrm{SE}$ & $\mathrm{R}$ & $\Delta \mathrm{E}$ \\
\hline Total disposal & 188 & 7 & 7) & 18 & 120 & 7 & $\begin{array}{l}+78^{* * *} \\
(9,8)\end{array}$ & 13 & $* * *$ & NS \\
\hline $\begin{array}{l}\text { Fetal-placenta! } \\
\text { transfer }\end{array}$ & 95 & 7 & 6) & 16 & 28 & 6 & $(9,8)$ & 10 & $* * *$ & NS \\
\hline Utilization & 97 & & 6) & 17 & 92 & 9 & $\begin{array}{l}+13 \\
(9,8)\end{array}$ & 8 & NS & NS \\
\hline Umbilical uptake & 88 & & 7) & 8 & 34 & 4 & $(9,8)$ & 9 & $* * *$ & ** \\
\hline $\begin{array}{l}\text { Endogenous } \\
\text { production }\end{array}$ & 12 & 11 & 6) & 13 & 58 & 8 & $(9,8)^{-30^{*}}$ & 12 & $* *$ & NS \\
\hline
\end{tabular}

$\mathrm{R}$, rest; $\Delta \mathrm{E}$, change with exercise; NS, not significant.

* $P<0.05$, ** $P<0.01, * * * P<0.001$

$\dagger$ For details of procedures, see p. 464.

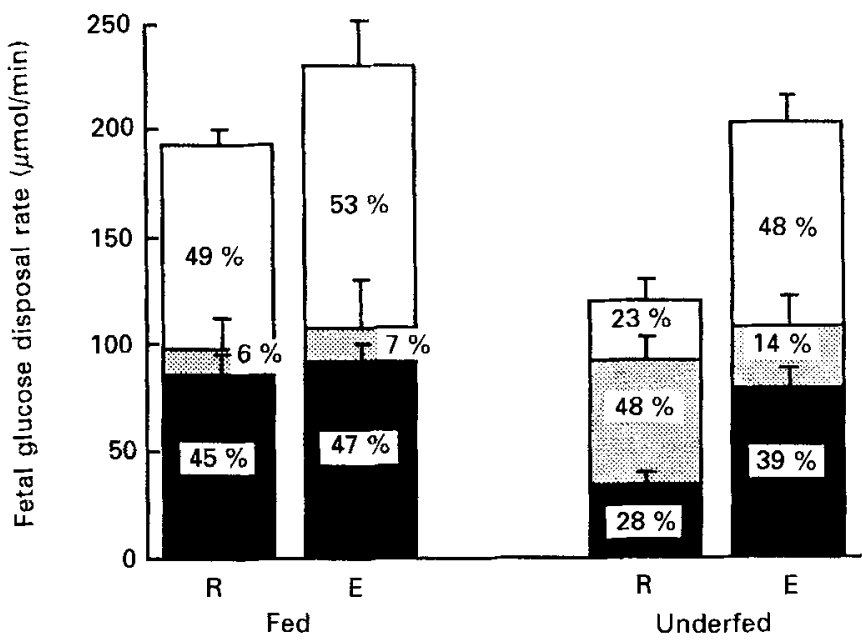

Fig. 1. Partition of fetal total glucose disposal rate between umbilical net uptake ( $\square$ ), endogenous production (图) and placental uptake $(\square)$ in fed and underfed ewes at rest $(R)$ and during exercise (E). For details of procedures, see p. 464. Values are means with their standard errors represented by vertical bars.

be greater in underfed than in well-fed ewes $(P<0 \cdot 1)$; the fetal glycaemic response was clearly greater in underfed ewes $(P<0.01)$. The maternal:fetal $\left[{ }^{14} \mathrm{C}\right]$ glucose SRA ratio decreased during exercise in fed ewes $(P<0.05)$ but was unchanged in exercising underfed ewes (Table 2).

\section{Fetal glucose kinetics}

Fetal total disposal rate, fetal-placental transfer and umbilical net uptake of glucose were substantially lower in underfed than in fed ewes (each $P<0.001$ ) (Table 3). In fed ewes, about $50 \%$ of glucose entering the fetal circulation was taken up by the placenta; this was 


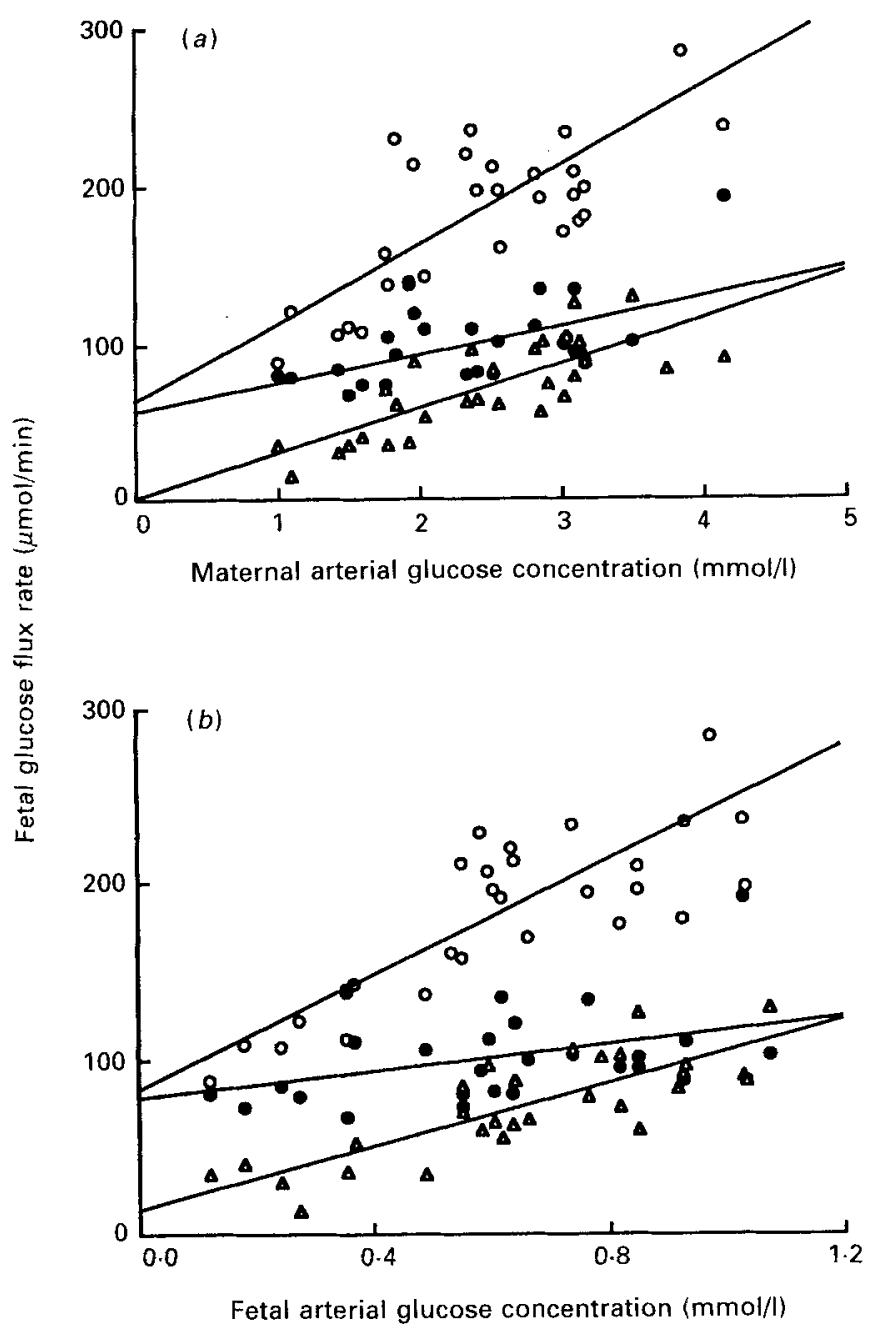

Fig. 2. Relations between $(a)$ maternal blood glucose concentration and $(O)$, fetal total glucose disposal rate $(y=49.9 x+61 \cdot 7, r 0.76, n 29, P<0.001)$, (O) fetal glucose utilization rate $(y=18.3 x+56.4, r 0.54, n 27$, $P<0.01)$ and $(\Delta)$, umbilical net glucose uptake $(y=28 \cdot 6 x+0 \cdot 2, r 0 \cdot 77, n 30, P<0 \cdot 001) ;(b)$ fetal blood glucose concentration and $(O)$, fetal total glucose disposal rate $(y=164 x+81, r 0 \cdot 84, n 29, P<0 \cdot 001)$, (O), fetal glucose utilization rate $(y=37 \cdot 6 x+77 \cdot 1, r 0 \cdot 38, n 27, P<0 \cdot 05)$ and $(\Delta)$, umbilical net glucose uptake $(y=90 \cdot 4 x+13 \cdot 0$, $r 0.82, n 30, P<0 \cdot 001)$.

reduced to $23 \%$ in underfed ewes. The remaining fraction, representing fetal glucose utilization rate, was not significantly affected by maternal plane of nutrition (Table 3). Fetal endogenous glucose production, estimated as the difference between fetal utilization rate and umbilical net uptake, was not significantly different from zero in fed ewes, but was substantially increased to a level which accounted for $63 \%$ of utilization rate in underfed animals $(P<0.01)$ (Table 3$)$. The fractional partition of fetal total glucose disposal rate between placental uptake, umbilical uptake and endogenous production in fed and underfed ewes during rest and exercise is illustrated in Fig. 1.

Exercise caused a significant increase in fetal total glucose disposal rate in fed $(P<0 \cdot 05)$ and underfed $(P<0.001)$ ewes (Table 3). In underfed, but not fed ewes, this was accompanied by a significant increase in fetal glucose taken up by the placenta $(P<0.001)$, 
which accounted for $85 \%$ of the increase in entry rate (Fig. 1). In fed ewes, rates of fetal utilization, umbilical uptake and endogenous production of glucose were unaffected by exercise. In underfed ewes, utilization rate was also unchanged, but umbilical uptake increased $(P<0.01)$ and endogenous production rate decreased $(P<0.05)$. Effects of maternal nutrition on exercise-induced changes in fetal glucose flux rates were significant for increased umbilical uptake $(P<0.01)$ (Table 3), and tended towards significance for increased placental uptake of fetal glucose $(P=0.06)$ and decreased endogenous glucose production $(P=0.09)$.

\section{Relations between maternal and fetal glycaemia and fetal glucose kinetics}

Individual findings for all treatments (fed, underfed, rest, exercise) were pooled for calculation of linear regression parameters and correlation coefficients, to describe general relations between fetal and maternal blood glucose concentrations, and between these and fetal glucose kinetics. Fetal arterial glucose concentration $(y)$ was related to maternal arterial glucose concentration $(x)$ by the equation: $y=0.29 x+0 \cdot 08, r 0 \cdot 88, n 32(P<0.001)$. Regressions of fetal total disposal rate, utilization rate and umbilical uptake of glucose on maternal and fetal arterial blood glucose concentrations are depicted in Fig. 2. The area between regression lines for entry rate and utilization rate represents fetal glucose taken up by the placenta, while the area between the lines for utilization rate and umbilical uptake represents fetal endogenous glucose production. Although statistically significant, correlations between these pooled values for fetal glucose utilization and maternal or fetal glucose concentration were relatively weak and not entirely incompatible with our failure to detect significant treatment effects on glucose utilization in group comparisons. It is apparent that as maternal and fetal glucose concentrations increased, so did placental uptake of fetal glucose, while fetal endogenous glucose production decreased. Both of the latter kinetic variables were more strongly correlated with fetal than with maternal blood glucose concentration (placental uptake $v$. maternal concentration $r 0.47, n 28, P<0.02$; placental uptake $v$. fetal concentration $r 0.65, n 28, P<0.001$; fetal endogenous production $v$. maternal concentration $r-0.27, n 27, P>0.1$; fetal endogenous production $v$. fetal concentration $r-0.42, n 27, P<0.05$ ).

\section{DISCUSSION}

The fetal kinetic findings presented in the present paper were obtained from a sub-group of ewes studied in the series of experiments reported in our preceding paper on partitioning of glucose between maternal and uterine tissues in the pregnant ewe (Leury et al. 1990). The present fetal findings can, therefore, be quantitatively related to the previously reported information on maternal and uterine glucose metabolism. However, the reduction in fetal weight in underfed ewes was smaller and not significant in the present study.

Until recently, a controversial issue in fetal metabolism has been whether or not fetal gluconeogenesis makes a significant contribution to the glucose requirements of the ovine conceptus (see Bell et al. 1987). Results of the present study have added in two ways to the mounting evidence that in well-fed, normoglycaemic ewes, fetal endogenous glucose production is of little consequence. First, the fetal:maternal SRA ratio of maternally infused $\left[{ }^{3} \mathrm{H}\right]$ glucose was close to unity, implying that almost all fetal glucose was of maternal origin (Anand et al. 1980; Hay et al. 1984). Second, the difference between fetal utilization rate and umbilical net uptake of glucose was not significantly different from zero, with mean umbilical uptake accounting for $91 \%$ of mean fetal utilization rate (Table 3). Similar findings were reported by Jones et al. (1983) and Hay et al. (1984). All three sets of results are consistent with a trivial rate of fetal gluconeogenesis, as shown more directly by the 
negligible conversion of ${ }^{14} \mathrm{C}$-labelled glucogenic substrates to $\left[{ }^{14} \mathrm{C}\right]$ glucose in the ovine fetal liver in vivo (Gleason \& Rudolph, 1985).

Our findings also support the notion introduced by Hay et al. (1984), that fetal endogenous glucogenesis becomes an increasingly important source of fetal glucose when maternal hypoglycaemia leads to dwindling uterine and umbilical glucose uptakes. Their suggestion was based on an apparent discrepancy between fetal utilization and umbilical uptake of glucose in ewes fasted for 5-7 d, athough this was statistically somewhat inconclusive. In the present study, the same measurements yielded a discrepancy which was not only significantly different from zero, but which accounted for $63 \%$ of fetal glucose utilization in ewes which had been severely undernourished for up to 3 weeks. This agrees closely with the recent demonstration, using identical methodology, that fetal endogenous glucose production accounted for $71 \%$ of fetal glucose utilization in ewes made chronically hypoglycaemic by maternal insulin infusion for about 3 weeks (DiGiacomo \& Hay, 1989). Our finding of a significant decline in the fetal:maternal SRA ratio of $\left[{ }^{3} \mathrm{H}\right]$ glucose in underfed ewes lends additional qualitative support for the idea that fetal endogenous glucogenesis is induced in chronically hypoglycaemic ewes.

The increased glucogenesis in fetuses deprived of maternal glucose for prolonged periods must reflect induction of gluconeogenesis, probably from glucogenic amino acids, in fetal liver and, perhaps, kidneys. The only alternative is hepatic glycogenolysis, and known stores of fetal liver glycogen in late gestation (10-20 g) (Shelley, 1961) could at most sustain the presently observed rate of fetal endogenous glucose production for about $30 \mathrm{~h}$. Thus, Lemons et al. (1986) found increased activities of key gluconeogenic enzymes in fetal liver and kidney from fasted ewes. Also, increased fetal urea synthesis in fasted and underfed ewes (Simmons et al. 1974; Hodgson et al. 1982) is consistent with increased fetal gluconeogenesis from amino acids. The glucose homeostasis of the late-gestation ovine fetus therefore appears to be regulated in a manner similar to that of the adult nonruminant animal, in which gluconeogenesis is invoked only when the exogenous (dietary) supply of glucose is insufficient to meet tissue requirements.

Fetal glucose availability in underfed ewes also appeared to be conserved by substantial reduction of placental uptake of fetal glucose for metabolism or transport back to the maternal circulation. A similar response was observed in sheep fetuses made chronically hypoglycaemic by maternal insulin infusion (DiGiacomo \& Hay, 1989) or placental growth restriction (carunclectomy) (Owens et al. 1989). Fetal-placental glucose transfer was more highly correlated with fetal than with maternal arterial glucose concentration, consistent with the reported dependence of uteroplacental net glucose consumption on fetal glycaemia (DiGiacomo \& Hay, 1989). As noted by these authors, placental transfer and consumption of glucose must be influenced by fetal endogenous glucose production, to the extent that it contributes to circulating glucose in the fetus. Also, although correlations between these kinetic variables and fetal glycaemia were statistically significant, their magnitude $(r<0 \cdot 7$, $R^{2}<0.5$ ) indicates the likely influence of other factors on fetal-placental glucose fluxes.

Fetal metabolic consequences of maternal exercise include hyperglycaemia (Chandler \& Bell, 1981; Bell et al. 1983) and in underfed ewes only, a major increase in umbilical net uptake of glucose (Chandler et al. 1985; Leury et al. 1990; present results, Table 3). Possible causes of fetal hyperglycaemia include (1) increased maternal glucose supply, related to the substantial increase in maternal glucose production rate and glycaemia (Leury et al. 1990); (2) increased fetal endogenous glucose production, perhaps mediated by stimulation of hepatic glycogenolysis in response to the mild to moderate fetal hypoxaemia observed during maternal exercise (Chandler \& Bell, 1981; Lotgering et al. 1983); (3) reduced fetal glucose utilization, which occurs during acute experimental hypoxia in fetal sheep (Jones et al. 1983). 
The present study has clearly demonstrated that most, if not all the fetal hyperglycaemic response to maternal exercise is due to increased entry of maternal glucose into the fetal bloodstream, with little or no change in fetal glucose utilization. In undernourished ewes, this increase in exogenous (maternal) supply considerably improved fetal carbohydrate balance by substituting for a large fraction of the fetal endogenous glucose production. Thus, endogenous production contributed only $27 \%$ of fetal glucose utilization during exercise, compared with $63 \%$ in resting, underfed ewes. This reduction in fetal glucogenesis (probably gluconeogenesis) is consistent with the depression of hepatic gluconeogenesis by infusion of exogenous glucose in adult sheep (West \& Passey, 1967).

The failure of fetal glucose utilization to be stimulated by increased glucose entry rate and hyperglycaemia confirms our earlier prediction, based on observations of unchanged fetal plasma insulin concentrations during maternal exercise (Bell et al. 1983). The substantial and rapid increase in fetal insulin during recovery from exercise (Bell et al. 1983), also seen during recovery from experimental hypoxia (Jones et al. 1983), suggests the possibility of increased fetal glucose utilization during the post-exercise period. Limited preliminary findings obtained from some of the sheep used in the present study are consistent with this suggestion (Leury, 1987). Under field conditions, the carryover effects of maternal activity on fetal glucose supply and utilization could be considerable, especially in undernourished ewes. In late-pregnant ewes fasted for $5 \mathrm{~d}$ and driven about $3.5 \mathrm{~km}$ in $1 \mathrm{~h}$, hyperglycaemia persisted for at least a further 4-5 h (Setchell \& McClymont, 1955), suggesting that enhanced maternal-fetal glucose transfer may have been similarly prolonged.

In conclusion, the development of fetal endogenous glucose production and reduced placental uptake of fetal glucose make important contributions to fetal glucose economy in severely undernourished ewes during late pregnancy. Despite these chronic adaptations, the fetus remains sensitive to, and is able to take advantage of, short-term improvements in maternal glucose supply, such as those occurring during exercise.

This work was supported by a grant from the Wool Research Trust Fund on the recommendation of the Australian Wool Corporation. The authors are grateful to Dr W. W. Hay Jr for his critical review of this manuscript.

\section{REFERENCES}

Anand, R. S., Ganguli, S. \& Sperling, M. A. (1980). Effect of insulin-induced maternal hypoglycemia on glucose turnover in maternal and fetal sheep. American Journal of Physiology 238, E524-E532.

Bell, A. W., Bassett, J. M., Chandler, K. D. \& Boston, R. C. (1983). Fetal and maternal endocrine responses to exercise in the pregnant ewe. Journal of Developmental Physiology 5, 129-141.

Bell, A. W., Bauman, D. E. \& Currie, W. B. (1987). Regulation of nutrient partitioning and metabolism during pre- and postnatal growth. Journal of Animal Science 65, Suppl. 2, 186-212.

Bergmeyer, H. U. \& Bernt, E. (1974). D-Glucose. Determination with glucose oxidase and peroxidase. In Methods of Enzymatic Analysis, pp. 1205-1215 [H. U. Bergmeyer, editor]. Weinheim: Verlag Chemie.

Boyd, R. D. H., Morriss, F. H. Jr, Meschia, G., Makowski, E. L. \& Battaglia, F. C. (1973). Growth of glucose and oxygen uptakes by fetuses of fed and starved ewes. American Journal of Physiology 225, 897-902.

Brodie, B. B., Axelrod, J., Soberman, R. \& Levy, B. B. (1949). The estimation of antipyrene in biological materials. Journal of Biological Chemistry 197, 25-31.

Chandler, K. D. (1983). Fetal and maternal responses to exercise in the pregnant ewe. M Agr Sc Thesis, La Trobe University.

Chandler, K. D. \& Bell, A. W. (1981). Effects of maternal exercise on fetal and maternal respiration and nutrient metabolism in the pregnant ewe. Journal of Developmental Physiology 3, 161-176.

Chandler, K. D., Leury, B. J., Bird, A. R. \& Bell, A. W. (1985). Effects of undernutrition and exercise during late pregnancy on uterine, fetal and uteroplacental metabolism in the ewe. British Journal of Nutrition 53, 625-635.

DiGiacomo, J. E. \& Hay, W. W. Jr (1989). Regulation of placental glucose transfer and consumption by fetal glucose production. Pediatric Research 25, $429-434$. 
Gleason, C. A. \& Rudolph, A. M. (1985). Gluconeogenesis by the fetal sheep liver in vivo. Journal of Developmental Physiology 7, 185-194.

Hay, W. W. Jr, Sparks, J. W., Quissell, B. J., Battaglia, F. C. \& Meschia, G. (1981). Simultaneous measurements of umbilical uptake, fetal utilization rate, and fetal turnover rate of glucose. American Journal of Physiology 240, E662-E668.

Hay, W. W. Jr, Sparks, J. W., Wilkening, R. B., Battaglia, F. C. \& Meschia, G. (1984). Fetal glucose uptake and utilization as functions of maternal glucose concentration. American Journal of Physiology 246, E237-E242.

Hodgson, J. C., Mellor, D. J. \& Field, A. C. (1982). Foetal and maternal rates of urea production and disposal in well-nourished and undernourished sheep. British Journal of Nutrition 48, 49-58.

Jones, C. T., Knox Ritchie, J. W. \& Walker, D. (1983). The effects of hypoxia on glucose turnover in the fetal sheep. Journal of Developmental Physiology 5, 223-235.

Lemons, J. A., Moorhead, H. C. \& Hage, G. P. (1986). Effects of fasting on gluconeogenic enzymes in the ovine fetus. Pediatric Research 20,676-679

Leury, B. J. (1987). Effects of undernutrition and exercise on glucose metabolism in the pregnant ewe. PhD Thesis, La Trobe University.

Leury, B. J., Bird, A. R., Chandler, K. D. \& Bell, A. W. (1990). Glucose partitioning in the pregnant ewe: effects of undernutrition and exercise. British Journal of Nutrition 64, 449-462.

Leury, B. J., Chandler, K. D. \& Bell, A. W. (1989). Fetal glucose metabolism during maternal exercise and undernutrition in pregnant ewes. Proceedings of the Nutrition Society 48, 93A.

Lotgering, F. K., Gilbert, R. D. \& Longo, L. D. (1983). Exercise responses in pregnant sheep: blood gases, temperatures, and fetal cardiovascular system. Journal of Applied Physiology 55, 842-850.

Meschia, G., Cotter, J. R., Makowski, E. L. \& Barron, D. H. (1967). Simultaneous measurement of uterine and umbilical blood flows and oxygen uptakes. Quarterty' Journat of Experimental Physiology 52, I-18.

Owens, J. A., Falconer, J. \& Robinson, J. S. (1989). Glucose metabolism in pregnant sheep when placental growth is restricted. American Journal of Physiology 257, R350-R357.

Setchell, B. P. \& McClymont, G. L. (1955). Reversal of the hypoglycaemia of fasted pregnant ewes. Australian Veterinary Joumal 31, $204-209$.

Shelley, H. J. (1961). Glycogen reserves and their changes at birth and in anoxia. British Medical Bulletin 17, $137-143$.

Simmons, M. A., Meschia, G., Makowski, E. L. \& Battaglia, F. C. (1974). Fetal metabolic response to maternal starvation. Pediatric Research 8, 830836.

Tsoulos, N. G., Colwill, J. R., Battaglia, F. C., Makowski, E. L. \& Meschia, G. (1971). Comparison of glucose, fructose and $\mathrm{O}_{2}$ uptakes of fetuses of fed and starved ewes. American Journal of Physiology 221, 234-237.

West, C. E. \& Passey, R. F. (1967). Effect of glucose load and of insulin on the metabolism of glucose and of palmitate in sheep. Biochemical Journal 102, 58-64. 